\title{
PEMBERIAN INFORMASI BAHAYA PENGGUNAAN NARKOBA SEBAGAI UPAYA PENINGKATAN KESEHATAN MASYARAKAT MELALUI GERAKAN KELUARGA SADAR OBAT DI KELURAHAN URUG KOTA TASIKMALAYA
}

\author{
Srie Rezeki Nur Endah ${ }^{1^{*}}$, Eddy Suhardiana ${ }^{1}$ \\ ${ }^{1}$ Universitas Perjuangan, Kota Tasikmalaya \\ *email: srierezekine@gmail.com
}

Diterima: 24 April 2019

Direvisi: 3 Mei 2019

Diterbitkan: 13 Agustus 2019

\begin{abstract}
The use of hazardous materials and illegal materials including drugs is also still prevalent as a result of the condition of society. Meanwhile the mass media, both electronic and print media, have not provided an educational role for drug issues, which is precisely the flood of drug advertisements that only utilize business aspects without regard to aspects of education in the field of medicine. People still need harder efforts from all parties to be able to understand medicine as a health commodity that must be safe, useful and quality. Community service activities are carried out to provide information on the classification of narcotics and psychotropic substances as well as the dangers of abuse so that the community can implement the Drug Conscious Family Movement. The method of implementing community service is carried out in two stages, namely the extension stage and active visit. Counseling and giving information will be given twice. Extension of the first stage regarding the classification of narcotics, psychotropic drugs and other dangerous drugs. The second phase of counseling is carried out by providing information and video visualization on the dangers of narcotics, psychotropic abuse and other dangerous drugs. The next step is to carry out active visits to residents' homes as a follow-up to the Conscious Family Movement Medication implementation program by demonstrating how to distinguish narcotics, psychotropic drugs and other dangerous drugs. The target of this activity is that Urug villagers Tasikmalay a city are expected to improve their quality of life such as self-medication and implementing the Conscious Family Movement Medication.
\end{abstract}

Keyword: Counseling, giving information, drugs, narcotics and psychotropic substances, Conscious Family Movement Medication

\begin{abstract}
ABSTRAK
Penggunaan bahan berbahaya dan bahan ilegal termasuk narkoba juga masih marak sebagai akibat kondisi masyarakat. Sementara itu media massa baik media elektronik maupun media cetak belum memberikan peran edukasi untuk masalah obat, yang ada justru banjirnya iklan obat yang hanya memanfaatkan aspek bisnis tanpa memperhatikan aspek edukasi di bidang obat. Masyarakat masih membutuhkan upaya lebih keras dari semua pihak untuk dapat memahami obat sebagai komoditi kesehatan yang harus aman, bermanfaat dan berkualitas. Kegiatan pengabdian kepada masyarakat dilaksanakan untuk memberikan informasi mengenai penggolongan narkotika dan psikotropika serta bahaya penyalahgunaannya sehingga masyarakat dapat melaksanakan Gerakan Keluarga Sadar Obat. Metode pelaksanaan pengabdian masyarakat dilakukan dengan dua tahap yaitu tahap penyuluhan dan kunjungan aktif. Penyuluhan dan pemberian informasi akan diberikan dua kali. Penyuluhan tahap yang pertama mengenai penggolongan narkotika, psikotropika dan obat-obat berbahaya lainnya. Penyuluhan tahap kedua dilakukan dengan memberikan informasi dan visualisasi video mengenai bahaya penyalahgunaan narkotika, psikotropika dan obat-obat berbahaya lainnya. Tahap selanjutnya yaitu dilakukan kunjungan aktif ke rumah warga sebagai tindak lanjut dari program pelaksanaan GKSO dengan mendemonstrasikan cara membedakan obat narkotika, psikotropika dan obat-obat
\end{abstract}


berbahaya lainnya. Target pencapaian dari kegiatan ini diharapkan masyarakat kelurahan Urug Kecamatan Kawalu Kota Tasikmalaya dapat meningkatkan kualitas hidup seperti swamedikasi serta melaksanakan Gerakan Keluarga Sadar Obat (GKSO).

Kata kunci: pemberian informasi, penyuluhan, obat, narkoba, GKSO.

\section{PENDAHULUAN}

Obat merupakan komoditi kesehatan yang berdimensi luas karena tidak saja terkait dengan kesehatan itu sendiri tetapi juga menyangkut aspek kehidupan yang lain termasuk aspek ekonomi, aspek teknologi maupun aspek sosial. Ditinjau dari aspek teknologi misalnya perkembangan obat sungguh luar biasa. Dimulai dari penggunaan bahan alam sebagai obat dengan mekanisme farmakologi sederhana, sekarang bergeser ke arah penggunaan bahan bahan kimia sintesis maupun non sintesis dengan sentuhan mekanisme sub seluler. Perkembangan bidang obat yang cukup pesat tersebut tentunya harus diikuti dengan peningkatan peran tenaga kesehatan untuk melakukan upaya kesehatan secara maksimal. Apalagi dalam Undang Undang Nomor 36 Tahun 2009 telah ditetapkan Upaya Kesehatan sebagai kegiatan yang bertujuan untuk meningkatkan derajat kesehatan yang setinggi tingginya bagi masyarakat dan salah satu kegiatan upaya kesehatan adalah pengamanan dan penggunaan sediaan farmasi dan alat kesehatan. Derajat kesehatan yang setinggi-tingginya seperti harapan yang tertuang dalam undang-undang kesehatan sampai saat ini masih belum tercapai. Berbagai masalah kesehatan, khususnya terkait obat masih ditemui di masyarakat. Mulai penggunasalahan obat, penyalahgunaan obat, terjadinya efek samping obat dari yang paling ringan sampai dengan kebutaan dan kematian, beredarnya obat palsu, narkoba dan bahan berbahaya lainnya, dan sebagainya. Salah satu penyebabnya adalah kurangnya kesadaran masyarakat akan obat dan sediaan farmasi lainnya, diperparah oleh adanya oknum yang mengambil keuntungan dari kondisi ini dengan menawarkan berbagai produk yang diklaim sebagai produk kesehatan. Penggunaan bahan berbahaya dan bahan ilegal termasuk narkoba juga masih marak sebagai akibat kondisi masyarakat. Sementara itu media masa baik media elektronik maupun media cetak belum memberikan peran edukasi untuk masalah obat, yang ada justru banjirnya iklan obat yang hanya memanfaatkan aspek bisnis tanpa memperhatikan aspek edukasi di bidang obat. Masyarakat masih membutuhkan upaya lebih keras dari semua pihak untuk dapat memahami obat sebagai komoditi kesehatan yang harus aman, bermanfaat dan berkualitas. Narkoba mempunyai dampak negatif yang sangat luas ; baik secara fisik, psikis, ekonomi, sosial, budaya, hankam, dan lain sebagainya. Bila penyalahgunaan narkoba tidak diantisipasi dengan baik, maka akan rusak bangsa dan negara ini. Oleh karena itu, diperlukan kerja sama yang baik dari seluruh komponen bangsa untuk penanggulangan penyalahgunaan narkoba.

Gerakan Keluarga Sadar Obat (GKSO) adalah program yang dicanangkan oleh Ikatan Apoteker Indonesia (IAI) yang merupakan upaya bersama untuk meningkatkan pemahaman masyarakat terhadap obat. Semua komponen bangsa, baik organisasi masyarakat, organisasi sosial, organisasi profesi, dan juga masyarakat sendiri harus bersinergi untuk meningkatkan pemahaman masyarakat terhadap obat dan tidak menyalahgunakannya termasuk narkotika dan psikotropika. Sampai saat ini masih banyak desa-desa di wilayah Tasikmalaya yang belum memahami mengenai bahaya menyalahgunakan narkotika, psikotropika dan obat berbahaya lainnya. Sehingga dengan adanya pemberian informasi tersebut masyarakat dapat melaksanakan Gerakan Keluarga Sadar Obat (GKSO). Salah satu daerah yang membutuhkan pemberian informasi obat adalah Kelurahan Urug Kota Kecamatan Kawalu Kota Tasikmalaya. Oleh karena itu, dengan adanya pemberian pengetahuan mengenai narkotika dan psikotropika diharapkan masyarakat mampu mengetahui bahaya dalam menyalahgunakan narkotika, psikotropika dan obat berbahaya lainnya.

\section{METODE}

Berdasarkan permasalahan yang dihadapi, kegiatan pengabdian pada masyarakat ini akan difokuskan pada pemberian informasi mengenai penggolongan narkotika dan psikotropika serta 
bahaya penyalahgunaannya. Adapun uraian dari metode pelaksanaan pengabdian masyarakat ini adalah sebagai berikut:

1. Observasi

Observasi awal dilakukan untuk menggali lebih dalam permasalahan yang muncul pada warga dengan metode kunjungan lapangan, dan wawancara langsung dengan warga. Data hasil observasi awal akan menjadi bahan untuk merencanakan dan menjalankan program pengabdian. Observasi lanjutan dilakukan untuk memulai kegiatan pengabdian masyarakat sehingga memastikan persiapan pengabdian yang akan dilaksanakan.

2. Rapat koordinasi

Rapat koordinasi dilakukan dua tahap, yang pertama koordinasi internal tim pengabdian. Dilaksanakan setelah mendapatkan data dari hasil observasi awal. Rapat koordinasi akan membuat perencanaan-perencanaan kegiatan pengabdian dan merumuskan solusi yang dapat ditawarkan, dan dapat dilaksanakan pada saat kegiatan pengabdian serta mempersiapkan seluruh kelengkapan yang dibutuhkan saat pelaksanaan pengabdian. Kedua rapat koordinasi antara tim pengabdian dengan mitra. Dilaksanakan melalui kegiatan temu lapang dan mensosialisasikan rencana kegiatan pengabdian yang telah dibuat tim pengabdian kepada mitra.

3. Penyuluhan

Tujuan dilaksanakannya penyuluhan ini adalah agar mitra diberikan informasi dan pengetahuan yang lebih paham yang difokuskan pada pemberian informasi mengenai penggolongan narkotika dan psikotropika serta bahaya penyalahgunaannya. Kegiatan yang dilaksanakan meliputi kegiatan penyuluhan dan pemberian informasi serta kunjungan aktif ke rumah warga di desa-desa. Metode pelaksanaan pengabdian masyarakat dilakukan dengan dua tahap yaitu tahap penyuluhan dan kunjungan aktif. Penyuluhan dan pemberian informasi akan diberikan dua kali. Penyuluhan tahap yang pertama mengenai penggolongan narkotika dan psikotropika dan obat berbahaya lainnya. Penyuluhan tahap kedua dilakukan dengan memberikan informasi dan visualisasi video mengenai bahaya penyalahgunaan narkotika dan psikotropika. Tahap selanjutnya yaitu dilakukan kunjungan aktif ke rumah warga sebagai tindak lanjut dari program yang akan dilaksanakan. Kegiatan ini dilaksanakan di RW. 09 Kelurahan Urug Kecamatan Kawalu Kota Tasikmalaya.

4. Evaluasi Kegiatan

Evaluasi kegiatan ini untuk mengetahui perkembangan hasil kegiatan berupa menguji kemampuan dan pemahaman warga RW. 09 Kelurahan Urug Kecamatan Kawalu Kota Tasikmalaya tentang penggolongan narkotika dan psikotropika dan obat berbahaya lainnya serta bahaya penyalahgunaannya.

5. Penyusunan Laporan Kegiatan

Tahap ini merupakan tahap akhir yang dilakukan pada kegiatan pengabdian masyarakat yaitu melakukan penyusunan laporan atas pelaksanaan pengabdian masyarakat yang sudah dilakukan.

\section{HASIL DAN PEMBAHASAN}

Kegiatan Pengabdian masyarakat Upaya Peningkatan Kesehatan Masyarakat Melalui Gerakan Keluarga Sadar Obat (GKSO) di Kelurahan Urug Kota Tasikmalaya diawali dengan melakukuan survey dan observasi pada tanggal 24 juli 2018 ke daerah Kelurahan Urug dengan mendatangi pihak Pimpinan dan Staf Kelurahan dan Puskesmas Kelurahan Urug yang sebelumnya sudah dikoordinasikan dengan pihak Dinas Kesehatan kota Tasikmalaya.

Pembukaan kegiatan dilakukan pada tanggal 15 Agustus 2017 di Aula Kelurahan Urug Kecamatan Kawalu Kota Tasikmalaya. Kegiatan ini dihadiri oleh Dekan Fakultas Ilmu Kesehatan, Ketua Program Studi Farmasi, dosen dan Asisten dosen Program Studi Farmasi, perwakilan mahasiswa Universitas Perjuangan, Pimpinan dan Staf Kelurahan, Kepala Puskesmas dan PromKes Puskesmas, Kader Posyandu, Kelompok Wanita Tani dan Tokoh Masyarakat Kelurahan Urug Kecamatan Kawalu Kota Tasikmalaya. Kegiatan secara simbolis dibuka oleh Dekan Fakultas Ilmu Kesehatan Universitas Perjuangan Tasikmalaya yang disambut antusias audien serta adanya sambutan dari Lurah dan Kepala Puskesmas Kelurahan Urug. Program umum kegiatan pengabdian masyarakat dipaparkan pada saat pembukaan kegiatan mengenai latar belakang, tujuan sampai ke indikator capaian yang diinginkan.

Pemusatan wilayah kegiatan pengabdian masyarakat Upaya Peningkatan Kesehatan Masyarakat Melalui Gerakan Keluarga Sadar Obat (GKSO) di Kelurahan Urug Kota Tasikmalaya 
dilakukan di RW.09 sesuai dengan kondisi warganya yang sedang diberikan program-program kesehatan oleh Puskesmas. Kegiatan Pengabdian Masyarakat ini memiliki persamaan dengan salah satu program yang ada di Puskesmas sehingga bisa dilakukan kerjasama dalam pelaksanaannya.

Kegiatan pengabdian masyarakat ini sedikit terhambat dengan keterlambatan waktu dikarenakan akses ke pemukiman RW.09 sempat terputus yaitu jembatan yang menghubungkan ke pemukiman. Kegiatan yang awalnya dilakukan pada bulan Agustus-September harus dipindahkan ke bulan November. Selain itu di puskesmas dengan sasaran kader poyandu juga mengalami hambatan karena diadakannya akreditasi puskesmas yang melibatkan semua pihak kesehatan masyarakat di kelurahan Urug Kota Tasikmalaya. Persiapan akreditasi puskesmas ini dimulai dari bulan Juli 2018 sampai dengan bulan Oktober, sehingga kami diperkenankan untuk melakukan acara penyuluhan pada pengabdian masyarakat ini dibulan November sampai dengan Desember.

Pemusatan wilayah kegiatan pengabdian masyarakat Upaya Peningkatan Kesehatan Masyarakat Melalui Gerakan Keluarga Sadar Obat (GKSO) di Kelurahan Urug Kota Tasikmalaya dilakukan di RW.09 sesuai dengan kondisi warganya yang sedang diberikan program-program kesehatan oleh Puskesmas. Kegiatan Pengabdian Masyarakat ini memiliki persamaan dengan salah satu program yang ada di Puskesmas sehingga bisa dilakukan kerjasama dalam pelaksanaannya.

Pemberian informasi dengan penyuluhan Gerakan Keluarga Sadar Obat (GKSO) dilaksanakan pada hari Selasa tanggal 13 November 2018 di pemukiman warga RW.09 Kelurahan Urug. Program GKSO yang diberikan adalah tentang penggolongan narkotika, psikotropika dan obat berbahaya lainnya. Kegiatan dihadiri oleh 40 orang yang pada umumnya merupakan ibu rumah tangga dan anggota PKK. Selain warga RW.09, sasaran lain yang mendapatkan penyuluhan ini adalah Kader Posyandu.

Pemberian informasi tahap selanjutnya pada tanggal 16 November selanjutnya yaitu dengan cara penyuluhan dan visualisasi video mengenai bahaya penggunaan narkoba. Dengan adanya pengetahuan mengenai jenis narkoba diharapkan masyarakat dapat membedakan obat narkotika, psikotropika dan obat berbahaya lainnya serta efek dan bahayanya bagi kesehatan.

Kegiatan selanjutnya yang akan dilakukan setelah penyuluhan yaitu adalah diadakan kunjungan aktif ke rumah warga. Kegiatan ini akan dilakukan pada hari Rabu tanggal 21 November 2018 dengan demonstrasi yang dilakukan dengan mempelajari nomor registrasi untuk obat dan narkotika, psikotropika dan obat berbahaya lainnya yang ada dalam setiap kemasan obat tersebut. Nomor registrasi tersebut sebagai salah satu indikator legalitas obat sehingga masyarakat dapat memahami cara membedakan obat dan penyalahgunaannya.

Evaluasi kegiatan dilakukan pada bulan sedember 2018 untuk mengetahui perkembangan hasil kegiatan berupa menguji kemampuan dan pemahaman warga RW. 09 Kelurahan Urug Kecamatan Kawalu Kota Tasikmalaya tentang penggolongan narkotika dan psikotropika dan obat berbahaya lainnya serta bahaya penyalahgunaannya yang diberikan dalam bentuk kuisioner terkait materi yang telah diberikan.

\section{SIMPULAN}

1. Masyarakat memahami tentang penggolongan obat narkotika, psikotropika dan obat berbahaya lainnya serta bahaya penyalahgunaannya cara pemberian informasi langsung dengan penyuluhan dan kunjungan aktif ke warga.

2. Masyarakat kelurahan Urug Kecamatan Kawalu Kota Tasikmalaya dapat melaksanakan Gerakan Keluarga Sadar Obat (GKSO) melalui program pemberian informasi tentang penggolongan obat narkotika, psikotropika dan obat berbahaya lainnya serta bahaya penyalahgunaannya sebagai upaya peningkatan kesehatan masyarakat.

\section{DAFTAR PUSTAKA}

[1] Anjelisa, dkk. 2010. Sosialisasi Cara Penggunaan Obat yang Baik melalui Penyebaran Poster dan Leaflet pada Unit Pelayanan Kesehatan di Lubuk Pakam Kabupaten Deli Serdang. Pengabdian Masyarakat. Tahun ke III. 
[2] Anief, M., 1996. Penggolongan Obat Berdasarkan Khasiat dan Penggunaan Cetakan ke 5, Gadjah Mada University Press, Yogyakarta.

[3] Anonim., 1995, Farmakope Indonesia, Edisi ke-4, Departemen Kesehatan RI, Jakarta.

[4] Anonim., 2014, Farmakope Indonesia, Edisi ke-5, Departemen Kesehatan RI, Jakarta.

[5] Ansel,H, C., 1989, Pengantar Untuk Sediaan Farmasi, Edisi ke-4, Universitas Indonesia Press, Jakarta. DepKes RI. 2009. Undang-undang Kesehatan No. 36 tahun 2009.

[6] Fendhyuhamka. 2011. Penggunaan Obat Pada Anak Dan Lansia Dalam: Serba Serbi Farmasi. Editor: Rusman. Jakarta: PT Gramedia.

[7] PPIAI. 2014. Pedoman Pelaksanaan Keluarga Sadar Obat.

[8] Widodo, R. 2004. Panduan Kelurga Memilih Dan Menggunakan Obat, Penerbit Kreasi Wacana, Yogyakarta. S. McNamara, J. Kent., and V. Dlovof, "Education based internet", Journal of Advanced Education 11 (2), 32-45 (2010)

[9] Eleanora, FN. 2011. Bahaya Penyalahgunaan Narkoba Serta Usaha Pencegahan Dan Penanggulangannya (Suatu Tinjauan Teoritis). Jurnal Hukum, Vol XXV, No. 1, April 2011.

[10] Ricardo, Paul. 2010. Upaya Penanggulangan Penyalahgunaan Narkoba oleh Kepolisian (Studi Kasus Satuan Narkoba Polres Metro Bekasi). Jurnal Kriminologi Indonesia Vol. 6 No.III Desember $2010: 232-245$ 